\title{
日本の皮䩷業の原皮
}

特にその主体定なす北米原皮について一一

川村亮

（東京跷工大学農学部）

Raw hides for Japanese leather industry

\section{Akira KAWAMURA}

(Faculty of Agriculture, Tokyo Noko University)

食品に怙ける動物蛋白資源の確保を計画生産の教く畜 産に求める傾向が強くなり，肉用家畜の短期肥育が非常 飞増加してきたこと致知の事実である。し加しその結 果として皮が大いに增産され，その取り扱いも变り同時 他肥育の影響で皮自身の品質も旧来のものと大变異って きたことに留意している人传少ない。特记この傾向はつ メリカに执いてはげしい，皮の增産はライフサイクルの 短い内用家畜が飼育されることと同時に雄も去勢の上肥 育する結果，絶対值としての枚数のほ为，個々の皮の面 皘増加む大いにあずかっている。現在迄の我䚮国の皮革 産業注年間 7,000万〜 1 億ドルの原皮を輸入し，端的に いって“原料皮はアメリカに，技術はドィッに”とい。 た姿で過ごしてきたのが実情である。従って日本の原皮

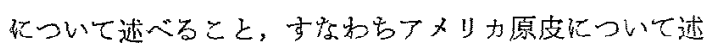
ベることと同義记近くなる。本総説においては日本の皮 勒産業に使用される原皮, 特汇輸入量の最も多いつメリ カ牛皮について最近の特色とその問題点を取り上げて見 ることとする.従って総説で怯あるが多少論説的色彩を 带びるものになることを扮許し願いたい。

\section{1. 日本の原皮消費量とその輸入割合}

我が国で昨年（1967 年）1力年消費された原皮の暴 計を重量で示して見ると第 1 表の如くである。

この表によると 1 力年に日本で消費された原皮は 22 万 余トンになるが，この内で輸入原皮の占める䧏合は $78 \%$ 儿近く，内地産のものは $22 \%$ 程展である。しか子恻入

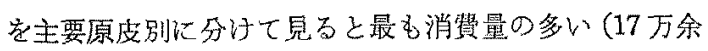

トン）牛皮の埸合はその $92 \%$ 以上を海外から輸入し， 内地産のるのはわずか7〜8\%沉過ぎない，乙れに対し 豚皮怯去の屠殺数から見る之牛皮の全消費量の $1 / 5$ 程度 の生産はあるはずであるが皮つきのまま食用に向けられ るものが多く实際に性先の0.6掛けの2 万余卜ンが皮草 用として活用され，表にはないがわずかながら（年間1 億円程度) 原皮としてもヨーロッパ等に輸出されてい る.緬山羊皮は牛皮の $1 / 50$ 程度の消費量であるが，その $90 \%$ 以上は輸入され，内 $40 \%$ 近くが(金額にして 19 億余円)，植物 タンニンによる半なめし (Semitanned) の状態で主としてインド，パキスタンより入っている。

次经同じく昨年の輸入原皮 (Semitanned の䌮山羊革 約 19 億円定除くつ通関実積を地域別の金額で見ると第 2 表の如くである。

すなわら全輸入原皮は金類にして 270 億円程度である が，この中で約 $65 \%$ が北米原皮である. 次いでオ一ス トラリアが 15\%，アジフ，欧州，南米炕なるといずれも 6〜7\%に下る. また輸入の内訳を見ると成牛皮致主と乙 て北米に，中小生皮注北米，欧州，オ一ストラリアに依 存し，緬山羊注フジフ，オーストラリフに，また䖯蠳 （主にワニ，上カダ皮）はアジア，北米，南米に，馬皮

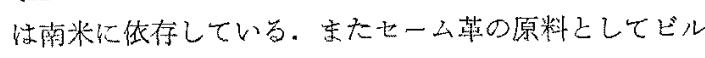
、，雲南等から魔皮が年間 3 億円程度榆入されている。

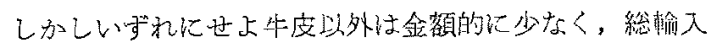

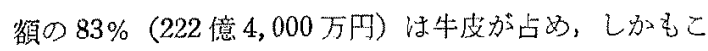

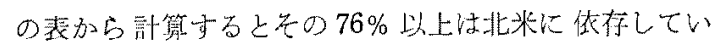
る勘定になる。 


$$
\text { 川 村 }
$$

第1表 日本に和いて 1 力年に使用した原皮量* (1967 年 1 12 月累計)

単位: $1,000 \mathrm{~kg}$

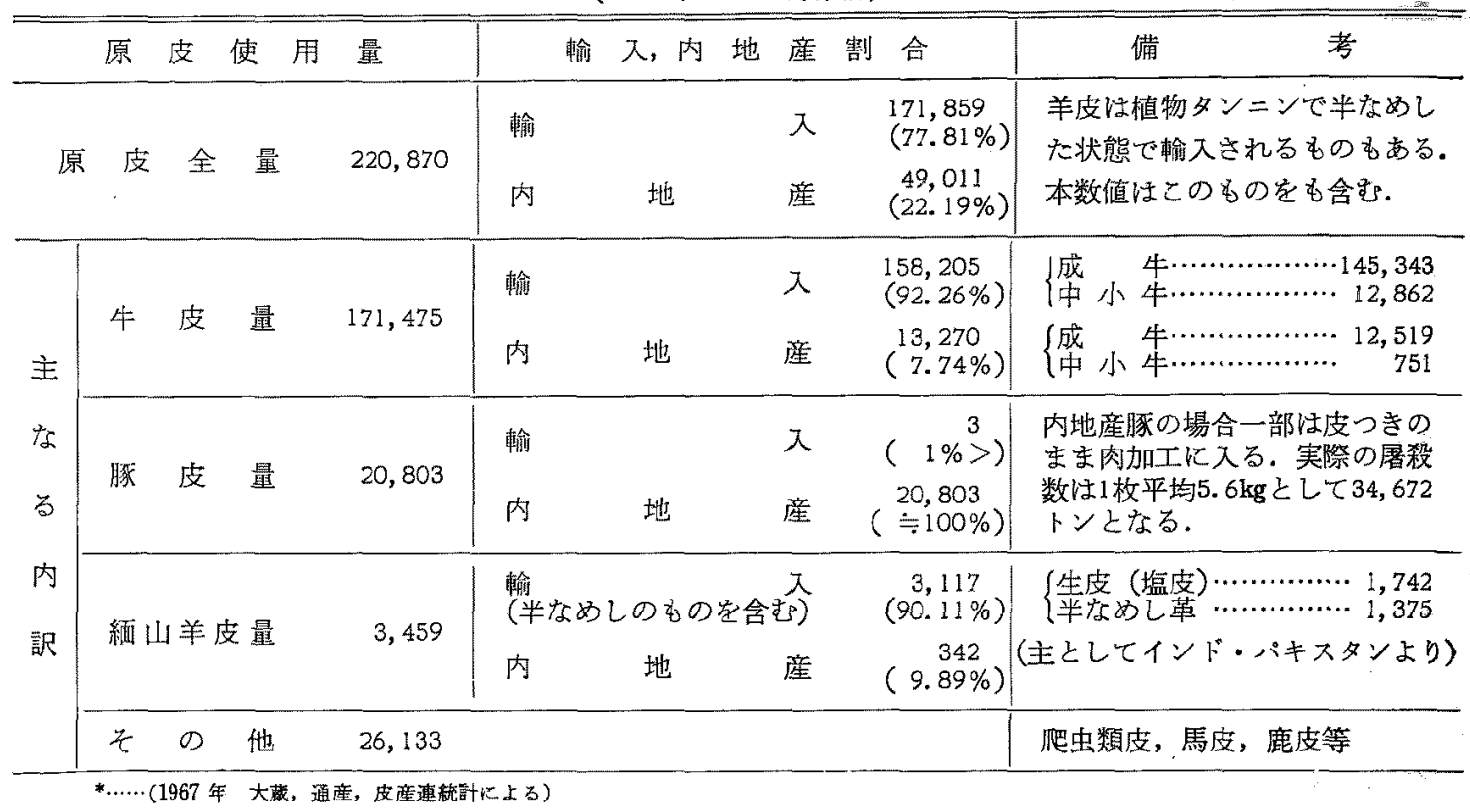

第 2 表 1967 年度輸入原皮支払金額**

(1967 年 1 月 12 月累計)

単位: 1,000 円

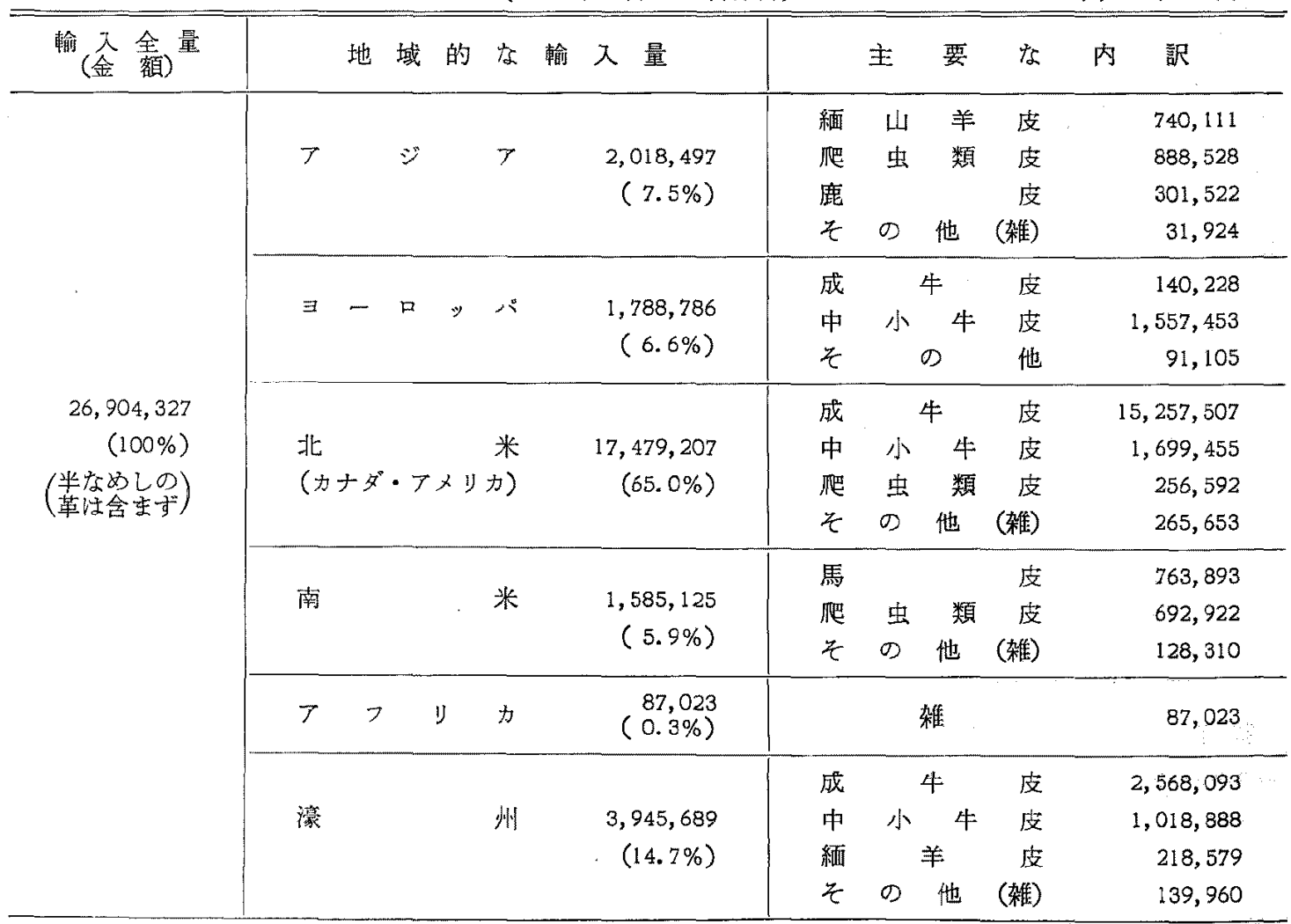

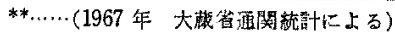




\section{日本の原皮}

牛皮はレザーとした場合，その組織，感触，強跔性， 厚度等あらゅ点で他の動物皮に比べて比類のない特色 意有し，一般に皮革工業でいら原皮结特に断りのない限 り牛皮を指すのが普通である。このように皮革工業の主 体在な牛皮が日本の場合北米一辺倒といらことは経済 的，貿易的観点から見てもいらいら之問題がある。しか あこの輸入ほ現在过極めて非科学的，投機的な信用買い で行なわれており実務家むよくこの不合理を指摘してい る処である ${ }^{38,511}$ 。

一般的にい。て皮勒産業梳，世界的に原皮の生産国々 革（レザー）の生産国とが必ずしも一致していないのが 普通でかる。例えば現在皮革裴品の生産で定評のあるイ タリー, ユーゴスラビア，チェコ，ドイッ，フランス 等は必式しる原皮の主要な生産国ではなく，これに反 し, 中南米, オ一ストラリア, アフリカ, インド, アメ リ等は原皮の生産国で注あるが必ずしも皮英産業の盛 んな処ではない，ただアメリカの場合は皮革産業も盛え であるが，原皮供給の増加の割に内需はのびていない。 例えば牛の屠殺数は 2,700 万頭 (1957) 加ら 3,420 万頭 (1966) に增加しているが内需はここ 10 年間 2,200 2,350万枚程度にとどまり，乙か子供給は 1980 年汽には さらに現在の $30 \%$ 增と推定されている。 ${ }^{88}$.

一方我分国においても，その畜産振興政策に伴い国産 原皮はここ 5 力年間に 3 万 7,842 トン (1962) 加ら 4 万 9,011 トン（1967）に増産され，特に豚は 2 万 981 トン (1962) 加䄪 1.5 倍の3万4,672トン（1967）に增加し ている，これらの豚原皮は欧州諸国に比べるとその利用 率が悪く，この高度利用の開発は今後大きな課題となる むのと思われる。な故原料皮，特に牛皮は艺の大部分が 塩皮の形で取り扱的れている。

\section{2.アメリカ原皮の品種ならびに飼育に基づく問題点}

アメリカの肉牛の主体となるのは Hereford, Black Angus, Shorthorn, Brahman で, このほが乳牛があ る、アメリカに限らず実際上の牛皮の分類法品種に上る

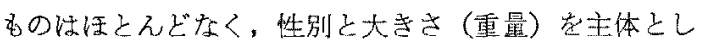
た分類 ${ }^{62,69}$ 方曾通である。も方万えこれは，皮から見て 品種的な差がないるけではなく幾多の特色があるが的，行， ${ }^{781}$ ，実際問題として肉を主体とするパッカーは皮のため K牛安品種別にするような労力定払わないことと，特に アメリカの場合は品種より肥育の影㗽の方が強く，一方 において品種間に交配も相当になされ，必ずしも純粋種 ばかりでないととも原因である。例えば Brahman はつ メリカには比較的近年入った牛で皮としては劣等である が, 品種的飞暑熱, ダ二, 昆虫等に強々, 多くの闪用牛
と交配され Santa Gertrudis, Brangs, Bradford, Beef

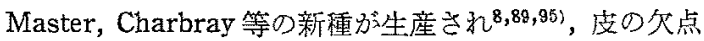
も著しくカバーされている75)。つぎ亿飼育のアメリカ原 皮にもたら方影響性甚だ大きい。

現在の肉牛の飼育法，特に米国に和けるそれは昔日の むのと大変異り，いわ功るフィードロットシステムが非 常比一般化して招り，このため受ける原皮の量的，質 的な影響は大きい。この方法は一定の大きさになった貸

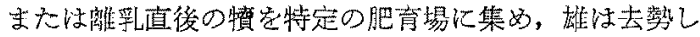
て浱厚飼料で一定期間肥育してから屠殺主るもので节る (Steer).フィードロット法に上る米国の肉牛の肥育忙 1930 年以前はいわゆるコーソベルトと呼ばれてい尚米 国中西部犬゙けで行なわれていたが，その後次第に米全 土，特に西部に应加り，飼料内容もコーンの利用とは限 らず各種の配合飼料が用いられるようになった ${ }^{881}$ ，現在 アメリカの肉牛の $70 \%$ はフィードロットより供給さ $れ^{75}$ ，管理，回転，皮の均一性等の点で良い点も多いが， また幾多の欠点を生ずる。まず第一の欠点は，フィー ドロットの発展性乳牛のステフーの肥育以李で及び，を の結棵としてカーフの皮は当然減少しつつあることであ る。現在フィードロットから屠場以送ら机てくる牛はス テアーで体重 1,050〜1,150 lbs, ハイフォー(Heifer)で $900 \sim 1,000 \mathrm{lbs}$ で雄と脽の割合汪概略 $3: 1$ 程度上され ている75)

フィードロットから出た重い皮で第一に問題となるの 注油斑（Grease Stain）が時々現われることで西る。す なわち裸皮や水革ではわからなが，これ乾懆した場 合，腎藏部からパット部沉かけて油による変色が起り， 革製品の大きな障管になることである。この油珽の問題 は米国以外の原皮にはほと九ど見られず，1930 年垻から

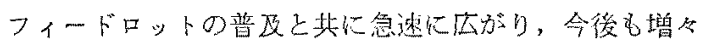
多発する傾向にある。油沚については O'FLAHERTY ${ }^{58)}$,

KREMEN \& O'FlaherT4 ${ }^{48)}$ が概説している. Clarise \&

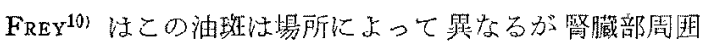
飞多く,皮中の脂肪の含量が $8 \%$ 以上飞なると明膫に現わ れステイン部の油は沃素価成比较的高いことを述べてい る. HIGHBERGER \& MOORE ${ }^{371}$ もこの油量の多いものは $27 \%$

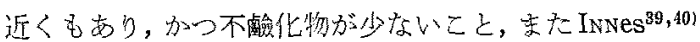
も油班部の油悱油斑部の油よりグリセライド形のもの

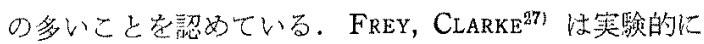
牛を 140 日〜10力月間飼育して艺の体重增加と皮の脂 肪合量との関倸調心，皮が央い程含脂量の高いととを 証し，また O'Flaherty, Ronny61)，Dempsey, Humphreys

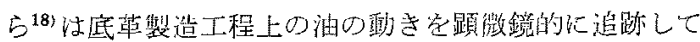
いる。油班は皮下脂肪汸塩藏中等に真皮層の中心浸透し 
たものとの考光もあったが999，HIGHBERGER, MOOREの塩

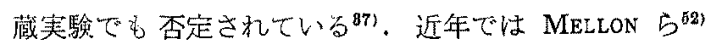
がステアー八イドについて油分の層別分析と脂肪酸租成 の研究定行ない，またBIrCOVER, MELLON ${ }^{6)}$ は先の研究に ついてさらに詳細炕層別, 部位別の油脂分の分析行な い，その分布を明らかにしワックスやステロールの含量 峙銀面に多く，グリセライドは肉面に最も多いこと，燐 脂質性銀面直下の層に多いこと, 特以腎臓部, 脚部, 腹 部に多いことを述べている。著者ら44)米国原皮につい てエタノールェーテル (3:1) の混液を用いて得たステ アーハイドの脂質をちイ酸カラムクロマトグラフィーを 使用して分離した結果，同様な結果を得ている．成田䛲 㳊数多くの米国原皮について工場的な実験を行ない，油 斑が次第僧加しつつあるこに，地域的には二ューヨー ク，デンバー，ロスアンゼルスのむのに多いとと，夏 皮，秋皮の方が発生率が高いこと等を確かめている。季 節による㾤すなかち，同じ重量でも冬，春ものに油斑の 少ない理由は，これらの皮は毛が長く，これがマニュフ (Manure) 等で活れやすく実際より重量が多く出るた

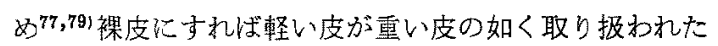
ことにあ関係があると推定されている.実際に緑の牧場 飞放牧されている時と異なり多数の牛がーカ所に收容さ れる結果，手入れの行きとどかない多頭飼育の欠点のみ が強調される場合も多い，例克ば雨の多い季節等は大変 污れがはぼしいことは著者むカルフォルニフの一部や コロラド等のフィードロットで実見した処である.さ らに問題となるのはこのような皮内にあるグリセライ ドは思いの妨披けにくいことである18,27,68,57,61)。少 なくとる普通の石灰溃程度の操作ではほとんど減少し ない27,46,47)，溶剂，加温，加圧等の併用が必要であるが 今もって完全なものはなく，むたこのような皮から充分 に脱脂すると皮自体は弱化してくる.

以上の上うに脂肪の問题のほか，短期の動物肥亩は二 ラーゲンそのものにも影響すると報告されている。 BowEs" らは羊皮とステアーについてこの問題を調べ, 普通で柱年令唯進むと共にコラーゲン自身も安定になっ てくるが短期肥育のものはコラーゲン量は充分あるが貿 的に法来熟で明らが性質が湋う。牛の場合でも短期肥 育のものは重量の都に面積は小さく，石灰漬中も膨化が 大きく，革にしても軟かいこと岩認加ている。

なお最近パルピーハイド (Pulpy Hide)なる障害が厚 物の Hereford の皮に見られるようになってきた。これ は1958 年オーストラリフの AMos"がはじめて報告した もので腎臓部に相当す吕処のコラーゲン瀻維が垂直に亚 えだ模浩のもので南米，ヨーロッパ，カナダ等にも発生
し,この部分は引き裂き強度にも弱く,肉面はカリフラワ 一状，銀面には波形のしわができ，むし多登すれば皮革と しては甚大な影㗽を被る。この障害はその脂肪含量とは 必ずしも比例せず真の原因ほ今もって明傕でないが，後 天的なものでも病害的なものでもなく，品種と改泉がも たらした变翼と考えられる。パルピーハイドについては

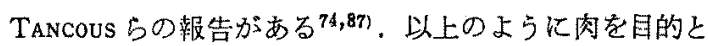
した飼育や改良の結果が従来の原皮には見られないいる いるな特色や障害をもたらして抢り，その上らな皮が我 が国の皮革資源となっていることを忘れてはならない。

\section{3. アメリカ原皮保藏の実態とその問題点}

皮は制波後㨁らになめしの準備作業に入ることはすれ で，普通には塩蔵処理 (Salt Curing)が行なおれる.塩 蔵には撒㫫法 (Conventional Pack Cure; 以下 P.C. 上 省略)，塩水瀆 ${ }^{14,15)}$ (Brine Cure; 以下 B.C. と省略) があ り, 後者法さらに振淈法 (Agitated B.C.) と静固法 (Pit B.C.)に分けられる。これらの具体的な方法ならびにその 経済性について注米国農業経済レポートNNo. $16^{900}$, No。 54 $4^{911}$ に良く記載されている。撒塩法は古くから行なるれ る方法でいう迄もなく皮を搪げては撒塩し，順次つみ重 小て take up 迄 4 週間程堆積する方法である. 同レポー トNo.1690)によるとP.C. 注 1 日当り 500 校の単位で处理 することが最む経済的で，これ以上ですこれ以下でる一 枚当りの経費性高くつく，換言すれば米国のデイラーと 商取引き苍する場合, 日産 500 枚程度のプラント已契約 することが最も有利であるが必ずしもその上うな好条件 の処恬かりはない，しからざる場合，デイラーは利閏索 多くするためにどこかで手抜くことになり，ここで不 完全なキュアーや一度使った污れた塩定再用するような

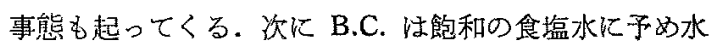
洗した皮を浸漬する方法で近年米国で盛んとなったもの である.この方法は P.C. と翼り一昼夜でキュアーが济

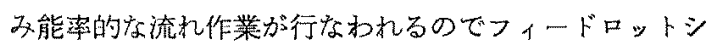
ステムとのコンビネーションには非常に適している. 先 のレポート ${ }^{901}$ によると原皮一枚当りの塩腎処理能率は一 人当り振湿 B.C.では 8.0 分同じく皮下組織や脂肪を除去 (fleshing)してから振湓 B.C.をしたものでは12.3 分, 同 じく静置 B.C. では15.1分である.これに対し従来の塩蔵 であるP.C.では14.7 分で，安大金頞的には日座 300 枚以 下ではP.C.の方が安く, 300〜500枚では大体变わらない

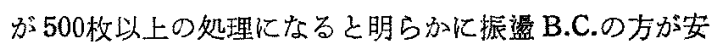
い.つまりB.C. は少なく之す基本的にはパッカーやデイ ラーの経済的見地加ら考案されたものて原皮の品筫向上 のために起ったものではない。な和現在のブラインキニ 


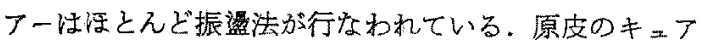
すなるち保蔵中に影響する要因として考光られるものに は，塩蔵前の放置時間，塩蔵条件，塩の品質また併用殺 菌剤の問題等がある、結諭を先にいうと, 純度の高い塩 が充分に使用されているなら原皮性それ程大きな劣化崖 起さないが堭蔵する迄に時間が経過すると年の劣化は甚 だしく，また爸化した皮革靲した場合，革自体の物理 性よりまず銀面が強影響をうけ，特に年令的に若いもの

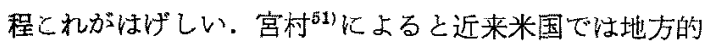
な食肉経済に結びっいたスモールパッカーが中西部の牛 の産地に堌加し，このためにディラ一の従来の倉庫に原 皮が集るのに時間を要する傾向が強くなり，パッカーで 不完全な仮塩をするようなケースが多くなっているとい 5. 次に B.C. 肪次第に普及するにつれ601，別な意味の 塩不足や，塩蔵遅延が起りやすくなっている．例えな゙日 産 500 枚処理する B.C. のプラントでは皮浸漬するバ ットのサイズがきまっているために，その数量以上に取 り报うことはできない，しかし実際に屠場から来る皮は 正確に 500 枚ではなく，これより少ないことむ多いこと あ方る. 今仮りに 600 枚が送られてきたとすると，過剩 の 100 枚は定数以上を収容してキニフーするか, 翌日儿 回主加せざるを得ない，前者の場合は直接塩の不足をき たし，をた後者の場合は普通の P.C. 希併用しない限り 塩蔵前の放置時間が非常に延長され，このために皮の劣 化が起る可能性も高い，古くから涂皮後時間が経つと塩 の皮への拡散速度が遅れるといわれている. HAUCK と LOLLAR ${ }^{33)}$ 注皮の劣化とこ礼からできる革の性質につい て200枚の皮を用いて大規模な試験を行なったが明確な 結果は得られな加った. DEMPSEY とROBERTSON ${ }^{17}$ は制皮 後の時間の变化上靴底革の関係について工場スケールの 研究を行なったがその物性には甚だしい違いはないが銀

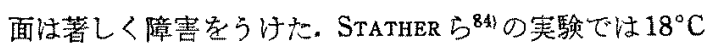
で死後 5〜24 時間放置のものは大きな差暴がないが 72 時間置いたものは劣化が顕著であった. HAUCKら ${ }^{\text {五) } の ~}$ 用した処によると，KAYE らは皮の組織変化を題微鏡的 亿研究，湓藏前 32 時間以上放䈯したものは少化が著明で

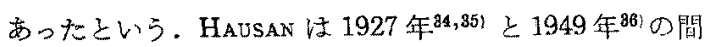
に出た塩蔵に関主る交献ををとめ, 塩は体温のなくなる とすぐ(剣皮後4〜6時間)やるべきであるとしている. また HAIN3 ${ }^{22)}$ は塩蔵力ーフを水漬, 脱塩後放置した際の 变化を觀察し，銀面と真皮の接合部からまず障害が起る

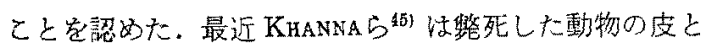
屠殺した動物の皮をクロム甲革に仕上げ比較したが，物 性に法変化がないが銀面に注明らかに差のあることを認 め, GAstellu, JULLIEN ら ${ }^{28,29)}$ も幼若な皮の最も特徵的
な損傷は銀面の斑と肉面の孔であるこ上を認めた。これ と並んで放置時間に関連して閣題になるのはプロテンビ 一フ (Proten Beef) と呼ばれている肉の熟成促進であ る76).これは現在, アメリカの大パッカーである Swift 社の特許沈なっているるので，生きている牛位静脈か ら蛋白分解醉素であるパパインを注入し，血流とともに 体内儿分布せしめ，死後の肉の軟化を棓るものである

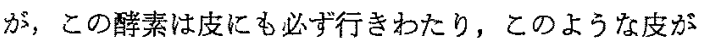
永く塩藏前に放置されるならば必ず何らかの影響を受け るはずであり，また塩藏中は酵素作用が阻害されていて も水漬，脱塩後も放置すれば残存した醉素による同様な 障害も考えられる。

さらに塩蔵で大きな問題となるの性 P.C. では古い塩 の再用の問題であり，B.C. ではプラインの濃度の問題で

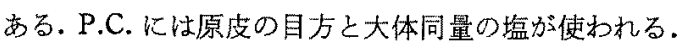
キニアー中绕生皮の水分注 $25 \%$ 近く失なるれ，同時比 盗が 7 8\%皮の方に增加する. 従って全体としては 17 18\%の目減りとなる. さらに皮中の血液や水分と 共に 22〜23\%の塩が失なるれるが，60\%近くの塩は回 収できる結果, ほとえど当然のことのように新塩と古塩 (used salt) が半々程度混用されている. 特に先に述べ た日産 500 枚処理以外の処では, 当然この使用割合が高 くなることはいう迄もない.しかもその混用がむらに行 なわれる結果，ある個処噺塩のみに，ある個処は古塩 のみに接することになる。著者ら ${ }^{66)}$ む缐敗の化学的指標 のひとつである非蛋白態窒素を塩蔵 40 日の皮で測定す ると古塩使用の場合は明らがこの量が增大した。古塭 再用の危険は古く MCLAUGHLIN ${ }^{50)}$ らも畒告している処

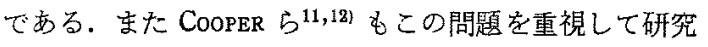
を行ないとの障害壳認め，少なくとも古塩は洗條使用す べきであるとしている，また O'FLAHERTY ${ }^{591}$ は污れた塩 注蛋白でカバーされ溶解度が低いこと指摘し， ANDERSON $^{22}$, SIMONCINI ${ }^{81,821}$ は抗塩菌の耐塩性吕連用に より增加すること究認め, 後者は $\mathrm{NaClO}_{2}$ の混用による 殺菌を提案している。この意味からも古塩の再用恬問題 である。岡村到に上るとオーストラリフの一部では古塭

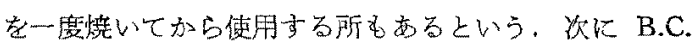
のブラインの漉度であるが，実際のキニア一の状態を見 ると，一度ブラインを使用して皮をあげても残った塩水 㹥容易にすてない. 所定の殺菌郕 (Na-Pentachlorophenolate; $\mathrm{C}_{8} \mathrm{Cl}_{5} \mathrm{ONa}$ ) と食塩定息加, 再用している. 6ち ろんこれらの液は一度パイプでフィルターに運ばれ浄化 されているが，現地で見る実際の榩度測定はボーメだけ で行なかれ，皮からの可溶性物質のブライン中への蓄積 に基らくボーメ浱度の上昇を余り考虑していない。この 
点も克分に警成を要する処である。

さらにP.C. に扮ける古塩再用にも関連して重要なの

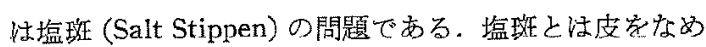
した後の銀面の一部が不規則にタラフト状に数雑になる 障害で，これが起ると皮革としての洒值艾非常に低下さ 好る。この原园は古くからキニア一に便われる $\mathrm{NaCl}$ 中 の不䋖物火由来するものとされていたが201，これに古塩 再用等に基づく細菌的皮の劣化もあず加ている. TANCOUS 女史 ${ }^{86}$ によると $\mathrm{NaCl}$ に夾雑する $\mathrm{Mg}$ が支質や

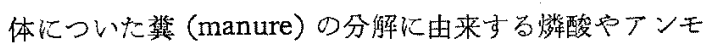
ニアと作用してます $\mathrm{NH}_{4} \mathrm{MgPO}_{4}$ となりこれが石厌漬

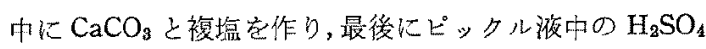
と作用して $\mathrm{CaSO}_{4}$ の結晶に变って銀面究傷害古るもの としている. しかして $\mathrm{NaCl}$ 中の $\mathrm{Mg}$ 量が 100 p.p.m. 程度でも既にこの障夆のおこる危検があるという。また

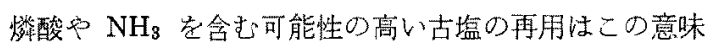

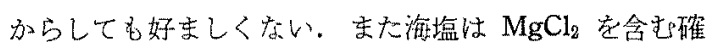

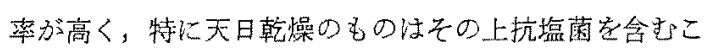
とも多いので，塩蔵に使用されている嗑についても原皮 購入に際しては十分注意する必要がある。幸いにして B.C. の筀合性皮方ら生ずる $\mathrm{NH}_{3}$ や燐酸が流去されるた

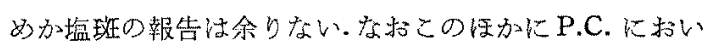

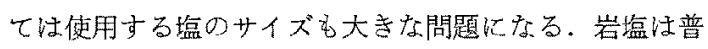
通に 3/8 インチ以下の大きさのものが使われるべきで, これ以上大きいもの法皮贵傷つけるだけでなく溶解浸透 がにら゙くこの間に支の劣化が起る591. しかしデイラー 法 take up に際して払い落した塩の量老多くするために 塩の粒の大きいものを使う可能性が高いのでここにも十

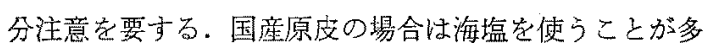
く徉ってサイズより吾しら $\mathrm{MgCl}_{2}$ の含量等の方が問題 で方る。なおーフの場合は筆者の知る限りでは塩藏は

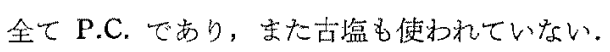

\section{4. 原皮保蔵時の殺菌剂}

塩蔵不適の原皮がどのような革になるかということは 別にして，保蔵状態の悪い場合，まず第一に目のつくの は一般に“Red heat”と呼ばれている紅色々䕀芳作る 抗賹菌の繁殖である. “Red heat”についてはてメリカ とイタリーが共同で詩細な報告21-24) 它出し菌の分雖を 行なっている。この障害は革にした場合は見加け程はひ ぞくないとされているが98，乙の祭殖程度を殺菌剂の效 果判空基华としていることが多い。最近 10年程のこの

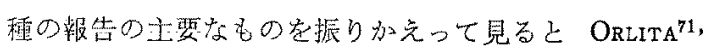
${ }^{72,78)}$ \& B.C. $飞$ 扎い $0.4 \%$ dichlorbenzene $\left(\mathrm{C}_{6} \mathrm{H}_{4} \mathrm{Cl}_{2}\right)$, $0.8 \% \mathrm{C}_{6} \mathrm{Cl}_{5} \mathrm{ONa}$ 等老添加することを推奖し，杍塩菌の
場合は酸でブラインの $\mathrm{pH}$ を下げることによって防止さ

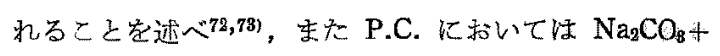

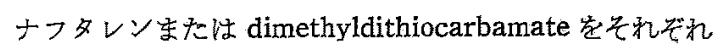
$\mathrm{NaCl}$ に $2 \%$ 程度加光ると大变良いことを報告してい

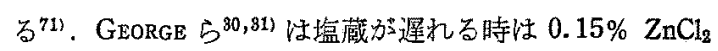

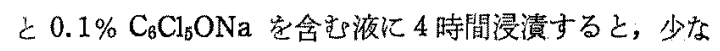

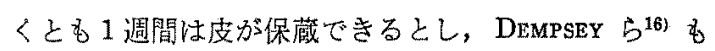
$\mathrm{C}_{6} \mathrm{Cl}_{6} \mathrm{ONa}, \mathrm{Na}_{2} \mathrm{SiF}_{6}$ ，ナフタンンの NaCl への併用学報告 している. また新し、殺菌削として米国の CORDON $b^{13)}$ は Benzalkonium chloride を推奖し,イタリ一の

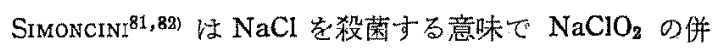

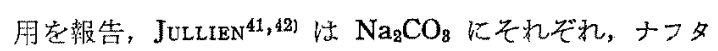
レソ, Dichlorbenzene $\left(\mathrm{C}_{6} \mathrm{H}_{4} \mathrm{Cl}_{2}\right)$, Trichlorbenzene $\left(\mathrm{C}_{6}\right.$ $\mathrm{H}_{3} \mathrm{Cl}_{8}$ ) 学併用試験し，いずれも良好な結果を得た各，特 に前者の中才ルト型のるのが優れていることを発表し

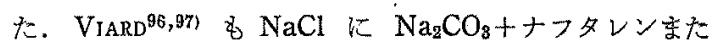
$\mathrm{C}_{6} \mathrm{H}_{3} \mathrm{Cl}_{8}$ の混用の効果索認めている. 一方に括いて抗生 物質の応用子広く考无られ, NANDY $5^{541}$ 注 NaCl $飞 0.5 \%$ の割で Streptmycin と $\mathrm{C}_{6} \mathrm{Cl}_{5} \mathrm{ONa}$ の $1: 1$ の混合物を加 光ること推せえし，BAyer $5^{4,5)}$ は Penicillin, Chlorotetracyclin, Oxytetracyclin, Chloramphenicol 等学加 えた NaClでキェフー些行ない,特に最後のものについて 大き效果它認好ている。著者 $5^{67)}$ \& Chlorotetracyclin について同様な効果学収めている。また昨年 (1967)。 テェコの国際原皮会旅で発表されたVIVIAN の報告 ${ }^{98)}$ はなかなか與味がある.これはニュージーランドから英 国に除出守る皮に熄斑や Red heat の障害が多いために この防止定目的として各種の殺菌用安試験し，結果とし て P.C. に際して㺹酸十ナフタレンを添加したものが最

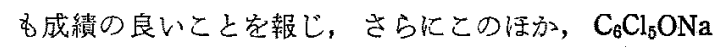
它併用したものはいずれの場合もなめした後の革に血管 の跡が目立つこと定述べている。近年我が国でもこのよ うな革 (Vein Leather) の多発加非常に問題になってい るが、アメリカの B.C. では現在いずれも殺菌刜として $\mathrm{C}_{6} \mathrm{Cl}_{5} \mathrm{ONa}$ を用いていること考古合せると大きな問題 があることが想像される，原皮をいかによく保蔵するか ということは皮革産莱の世界的な大問題である。しかし 最近 10 力年程の間に目のついた皮の殺菌用関係の報告 35 編程家通じてその的とえどがフランス，チェ士，英国， イタリー等のむしろ原皮の輸入側に立つ国々によって行 なるれたるので最大の原皮倛給国たるアメリカの報告は わずか数編に過ぎない.このことはケメリカ原皮一辺倒 の日本によってはたえに $\mathrm{C}_{6} \mathrm{Cl}_{5} \mathrm{ONa} の$ 可否の問題のみて

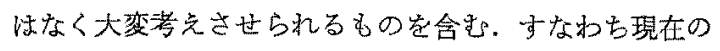
アメリカの情況下では, 塩蔵前に原皮が長時間放置され 
る危険も古塩再用以よる劣化の危除も充分西るにるかか わらず，その防止のための殺菌戍が余り重視されていな

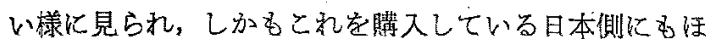
とえどその研究がない，しかるる他の国々では自らこれ 研究し，自国産の原皮はもちえ万，輸入原皮炕子科学的 な根拠に基づく合理的なオーダー它している可能性があ るからである。な打㣺で注 P.C. の場合でもカーフの

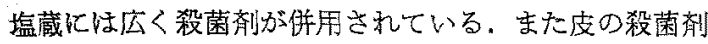
の本質的な条件注，皮蛋白沉不可逆な变化を与えないこ とであることはいら迄もない。

\section{5. アメリカ原皮のその他の問題}

アメリカ原皮で肥育，保蔵等のほ政問題になるのはそ の広大な土地柄に由来する産地别の差異である。地域别 の特色は，たえに皮質の問題だけではなく，その地域独 特の障害, 例光ばグラブ (Grub), 提き症 (Scratch), 烙 印 (Brand) 等が伴い易く，少なくとも昔はとの原皮を 生産した屠場が判ると原皮判定の大きな目安となった。 しかし現在で活全土をぬ゙るハイウェイの発遥, フィー ドロットの発展から牛の移動がはげしくなり，ひとつの 屠場で殺された牛が必すしも地域の牛ではなくなっ てきている.アメリカ原皮の地域別特色については大 木 $^{700}$ が，免たその取引の実情については大本 ${ }^{703}$, 岡村64 が記述し，またアメりカ原皮の一般については米国 National Hide Association 出版の図書 ${ }^{56)}$ が岁り, 原皮 の障害についてはTANCOUS らの著畫85)，また一般的には 大林8)，岡村ら ${ }^{63)}$ の概説が，主た北米厚物原皮について 注清水の著書 ${ }^{80}$ がある。また主に経済性からきたアメリ カ原皮のトリーミングの型については米国通産省発行の

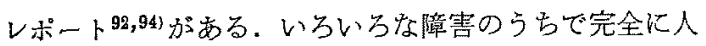
工的なものでありながらフメリカ原皮の瑟い方の特色の

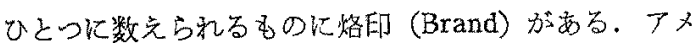
リカ牛皮の $50 \%$ 以上これが的原皮として注大きな障 害になっている. 特徆西部山脈地带（モンタナ゙, ワイオ ミンダ, コロラド, フリゾナ，ユタ等）の広大なランチ の中の牛は大形のブランドを持つあのが多い.ブランド の改良は古く名ら問題になっているが，最近凍結プラン

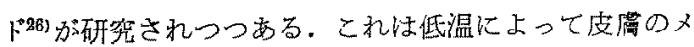
ラニン層の機能を破壎し，ここ加ら生ずる毛が白毛とな るもので，烙鉄よりはるが小さ印でも良く見先る。 皮にした時にはやはり傷恃残るが烙鉄のようにひどくは 校い.

なた同しく人工的な障害であるナイフカットは皮制ぎ が電気ナイフと機械はき (Pull flay) になってきたため 非常に隇少している.

\section{6. 結政}

原皮の關題性をの関連方当分野が広く，いるいるな角 度からこ礼見ることができる。例えば経済学的, 組織 学的, 生化学的, 蛋白化学的, 音産学的, 工業化学的, 高分子化学的等いずれも立派総説をなし得るものであ る.

本総説では日本という限られた立場から産業的に最も 依存度の高いアメリカ原皮定特に近来，問題になってい る油斑と保蔵定中心として述べて見た。現在のシステム では飼育，保藏いずれの面からも日本の輸入原皮は本質

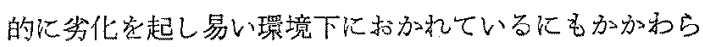
ず，わが国ではこの問題を積極的に研究する気運が極め てそしい，これはひとつには原皮の問題は原因方外国に おける事像で日本では自由にできないことと放率してい る向きにもあるが皮革自体への一般人の関心の薄いこ と，産業的に大会社は一部に限られ小企業や零細企業熊 のものが多く，基本研究を可る幅とりのないとと等があ げられる，皮革はレザーになったもの趕価計算すると その70\%以上が原皮代である ${ }^{48)}$. 従って原料皮の品質

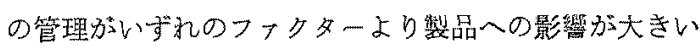
ことはいう宋でもない，現在の原皮は極く一部に乾皮も あるが大部分は塩蔵である。勿論塩蔵がなくなることは ないにしても，次の時代にこれ以外の保蔵の考劣られる ととす当然で，既につせトン脱水 ${ }^{8,49)}$ ，放射線利用 ${ }^{9,19 !}$

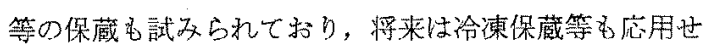
られるであるう。また原皮を現地で脱毛，ピックルして いわ呀るビーミング (Beaming) の皮として保蔵や輸送

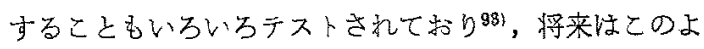
うな原皮が輸入される可能性も高い。また我が国では液 相, 固相においてコラーダン瀻維安再生利用寸る道む開 発されつっあり，レザーこして不向きな部分在この方面 へ利用することも広く考充られ，一方に利いて本邦で唯 一の増産体制にある朕皮の利用は今な打非常に低、段階 に留安り、これらの高度利用の意味からも原料皮乞のも のの認識上研究はな拈一層の重要性定有するものであ 亏.

また日本で輸入する原皮の主力がフカリカ一辺倒とい うこ己も大いに反省さるべき問題で，我が国の経済面と

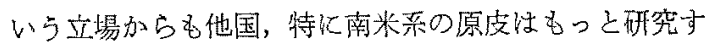
ることが必要である。

文 献

1) Amos, G.L. (1958) J.S.L.T.C., 42: 79-90.

2) Anderson, H. (1945) J.S.L.T.C., 29: 215.

3) Batrles, M. (1960) Leather Manufr., No. 5: 32. 
4) BAyer, Z., E. LudvigER and V. Johanides (1959) Cuoio pelli mat. concianti, 35: 477-485.

5) Bayer, Z., E. Ludviger and V. Johanides (1960) J.A.L.C.A., 55: 368-369.

6) Bitcover, E.H. and E.F. MeLlon (1966) J.A. L.C.A., 61: 338-350.

7) Bowes, J.H. and A.S. Raistrick (1968) J.A. L.C.A., 63: 192-209.

8) BRIGGs, H.M. (1958) Modern Breeds of Livestock, MacMillan Co. New York.

9) CAssel, J. (1959) J.A.L.C.A., 54: 432-451.

10) Clarke, I.D. and R.W. Frey (1933) J.A.L.C. A., 28:416-423.

11) Cooper, D.R. and A.C. Galloway (1966) J.A. L.C.A., 61: 162-170.

12) Cooper, D.R. and A.C. Galloway (1967) J.A. L.C.A., 62: 174-180.

13) CoRdon, T.C., H.W. Jones and J. Naghski (1964) J.A.L.C.A., 59: 317-326.

14) De Beukelaer, F.L. (1956) Preservation of Hide and Skin, edited by O'Flaherty et al., Chemistry and Technology of Leather, 194-218, Reinhold Publishing Co. New York.

15) De Beukelaer, F.L., E.J. Strandine and D.W. Kaufmann (1956) Brine Cure Process, edited by National Hide Assoc., Hides and Skins, 33-62, Jacobsen Publishing Co. Chicago.

16) Dempsey, M. and B.M. Hairs (1964) J.S.L.T.C., 48: $424-438$.

17) Dempsey, M. and M.E. Robertson (1948) Progress in Leather Science, 104-105, British Leather Manufacture's Research Association, London.

18) Dempsey, M., G.H.W. Humphreys and M.E. ROBERTSON (1951) J.S.L.T.C., 35: 117-133.

19) Dempsey, M., G.H. GreeN and J.A. Moss (1965) J.S.L.T.C., 49: 386-396.

20) Eitner, W. (1913) Collegium, 519: 397-399.

21) Formisano, M. (1962) Cuoio pelli mat, concianti, 38: 11-45, 100-131, 183-213, 325-346.

22) Formisano, M. (1963) J.A.L.C.A., 58: 495.

23) Formisano, M. (1964) Investigation on "Red heat", Stazione sprimentale per l'industria delle pelli e delle materie concianti, Naples.

24) Formisano, M., A. Simoncini and A.Meduri (1963) Cuoio pelli mat. concianti, $39: 3$.

25) Formisano, M., A. Simoncini and A. Meduri (1964) J.A.L.C.A., 59: 623-624.

26) Freeze Branding as an International Animal Identification System (Article Published Jan., 5 th., 1967, issue of the Washington Farmer)

27) Frey, R.W. and I.D. Clarke (1933) J.A.L.C. A., 28: 490-511.

28) Gastellu Ch., I. Jullien, J. Prevot and A.M. Cinistry (1959) Bull. assoc. franc. chimistes inds cuir, 21: 16-23.

29) Gastellu Ch., I. Jullien, J. Prevot and A.M. CinistRY (1959) J.A.L.C.A., 54: 668.

30) George, E.C. and V.S. Krishnamurty (1966) Indian Leather Technologist Assoc., 14: 4-9.

31) George, F. C. and V. S. Krishnamurty (1967) J.A.L.C.A., 62: 286.

32) Hains, B.M. (1953) J.S.L.T.C., 37: 363-374.

33) HAuCK, R. and R.M. Lollar (1957) J.A.L.C.A., 52: 361-393.

34) Hausan, W. (1938) Collegium, 814: 55-78.

35) Hausan, W. (1939) J.I.S.L.T.C., 23: 44.

36) Hausan, W. (1950) Das Leder, 1: 18-20, 47-50, 69-70.

37) Highberger, J.H. and E.K. Moore (1934) J.A. L.C.A., 28: 16-37.

38）平塚良辰 (1960) 草加皮革研究会誌，2：2-4.

39) InNEs, R.F. (1939) Leather World, 31: 31.

40) InNES, R.F. (1940) J.A.L.C.A., 35: 356.

41) Jullren, I. (1962) Bull. assoc. franc. chimistes inds cuir, 24: 118-124.

42) Jullien, I. (1962) J.A.L.C.A., 57:546.

43），川村 亮 (1962）高分子，11：1259-1265.

44）川村 亮・和田敬三・川㥓 信: 未発表.

45) Khanna, K., S. C. Nandy, R. RaO and Y. Nayudamma (1966) Leather Sci., 13: 339-349.

46) Koppenhoffer, R.M. (1937) J.A.L.C.A., 32: 210-230.

47) KopPENHOFfER, R.M. (1937) J.A.L.C.A., 32: 380-396.

48) Kremen, S.S. and F. O'Flaherty (1953) Leath. Manfr., 64: 9-10.

49) Kremen, S.S., R.L. Southwood (1960) J.A.L. C.A., 55: $24-40$.

50) Mclaughlin, G.D., I.H. Blank and G.E. ROcKWELL (1928) J.A.L.C.A., 23: 300-318.

51）宮村信行（1960）皮革技術， 1 (2)：3-8.

52) Mellon, E.F., S.H. Herb, R.A. Barford, S.T. VIOLA and F.E. LUDDY (1962) J.A.L.C.A., 57: 26-35.

53) MoORE, E.K. and J.H. Highberger (1935) J.A. L.C.A., 30: 2-26.

54) Nanday, S.C. and S.N. Sen (1962) Bull. Central Leather Research Inst., Madras, 1: 12-20.

55) 成田 弘 (1958) 皮技協誌別輯 1 号: 13-33.

56) National Hide Association (1956) Hides and Skins, Jacobsen Publishing Co., Chicago.

57) NaucK, R. and R.M. Lollar (1956) Leath. Manfr., 73: 5.

58) O'Flaherty, F. (1949) Leath. Manfr., 60: 284.

59) O'Flaherty, F. (1961) Salt Its Role in Cure. Tanner's Council Lab., Univ. of Cincinnati, Nov.

60) O'FlaherTy, F. (1962) J.A.L.C.A., 57: 71-77.

61) O'Flaherty, F. and W.T. Roddy (1935) J.A. L.C.A., 30: 290-311. 
62) 岡村 浩 (1967) 皮革技術（甲革の原皮・準临作 業特集), 8 (2)：3-4.

63) 岡村 浩 (1967) 同上, 8 (2): 3-21.

64) 同村 浩 (1967) 同上, 8 (2): 5-7.

65) 岡村 浩 (1967) 同上, 8 (2): 18.

66) 岡村 浩·諸橋悠紀治・川村 亮 (1966) 皮革化 学, 11: 191-194.

67）岡村 浩·諸橋悠紀治・川村 完 (1966) 同 上, 12: $1-4$.

68）大橲久寿 (1956) 皮技協誌，1：71-80.

69）大橲久寿 (1956) 同上, 1: 74-75.

70) 大本喜久寿 (1960) 皮革技術, 1 (1)：12-14.

71) ORLiTA, A. (1967) Present State and Expected Development of Curing Hides and Skins, Lecture for Intern. Conference of Raw Hide, Sept., Gottwaldov C.S.S.R.

72) ORLiTA, A. (1967) Kozarstrv., 17: 102-104.

73) ORLITA, A. (1968) J.A.L.C.A., 63: 144.

74) Ornes, C.L., J.J. Tancous and W.T. RoddY (1964) J.A.L.C.A., 59; 4-14.

75) Potrer, G. (1967) Breed and other Factors affecting Raw Hide Quality, Lecture for Intern. Conference of Raw Hide, Sept., Gottwaldov C.S.S.R.

76) Robinson, H.E. and P.A. Goeser (1962) J. of Home Economics, 54: 195-200.

77）清水和光 (1957) 皮技協誌, 3: 141-146.

78）清水和光 (1958) 底革，52-59，パシフィタオー バーシーズ K.K.

79）清水和光 (1958) 同上, 31-43, 同上.

80）清水和光 (1958) 同上, 31-112, 同上.

81) Simoncins, A. (1963) Cuoio pelli mat. concianti, 39: 154.

82) Simoncini, A. (1964) J.A.L.C.A., 59:623.

83) SNapp, R.R. and A.L. Neumann (1960) Beef Cattle, 295-314, John Wiley and Sons Inc., New York.

84) Stather, F. and H. Herferd (1936) Collegium, 792: 215.
85) Tancous, J.J., W.T. Roddy and F. O'Flaherty (1959) Skin Hide and Leather Deffects, The Western Hill Publishing Co., Cincinnati, Ohio.

86) Tancous, J.J. (1960) J.A.L.C.A., 55: 66-78.

87) Tancous, J.J. (1966) J.A.L.C.A., 61: 4-24.

88) Thompson, J.W. (1967) Hide Leather and Shoe Marketing in the United States, Lecture for Intern. Conference of Raw Hide, Sept., Gottwaldov C.S.S.R.

89) U.S. Department of Agriculture (1958) Beef Cattle Breeds Farmer's Bulletin No. 1779.

90) U.S. Department of Agriculture (1962) Marketing Economic Division: Four Hide Curing Methods, Agr. Economic Reoprt No. 16.

91) U.S. Department of Agriculture (1964) Marketing Economic Division: A Guide to Lower Costs and Greater Efficiency in Curing Cattle Hides, Agr. Economic Report No. 54.

92) U.S. Department of Agriculture (1965) Alternative Markets for Cattle Hide Trim, Econmic Research Service Report No. 217.

93) U.S. Department of Agriculture (1967) Economic Aspects of Unhailing Hides at the Packinghouse, Marketing Research Report No. 797.

94) U.S. Department of Commerce $(1965,66)$ Hide Trim Pattern Domestic Cattle Hide, Commercial Standard C.S. 268-65 and Amendment No. 1.

95) Van Arsdell, W.J. (1956) Type, Breed and Characteristics of Cattle, Hide and Skin (National Hide Assoc.) 1-6.

96) VIARD, M. (1962) Bull. assoc. franc. chimistes inds cuir, 24: 125-138.

97) VIARD, M. (1962) J.A.L.C.A., 57: 545-546.

98) Vivian, G.W. (1967) The Preservation of Hides and Skins against Bacterial Damage, Lecture for Intern. Conference of Raw Hide, Sept., Gottwaldov C.S.S.R.

99) White, P. and F.G. Caughley (1934) J.A.L. C.A., 29: 313-320. 